\title{
Synthesis and pharmacological evaluation of 3-cyclohexyl-2-substituted hydrazino-3H-quinazolin-4-ones as analgesic and anti-inflammatory agents
}

\author{
VEERACHAMY ALAGARSAMY ${ }^{1, *}$ \\ DURAIRAJ SHANKAR ${ }^{2}$ \\ VISWAS RAJA SOLOMON ${ }^{3}$ \\ RAJENDRA VASANT SHEOREY ${ }^{4}$ \\ PERIYASAMY PARTHIBAN ${ }^{1}$ \\ ${ }^{1}$ Medicinal Chemistry Research \\ Laboratory, MNR College of Pharmacy \\ Sangareddy-502294, India \\ ${ }^{2}$ Department of Pharmacy (CARISM) \\ SASTRA University, Tirumalaisamudram \\ Thanjavur-613402, India \\ ${ }^{3}$ Medicinal \& Process Chemistry \\ Division, Central Drug Research \\ Institute Lucknow-226001, India \\ ${ }^{4}$ Department of Pharmacology \\ Institute of Pharmacy, Raipur Institute \\ of Technology Raipur-492001, India
}

\begin{abstract}
A series of novel 3-cyclohexyl-2-substituted hydrazino-quinazolin-4(3H)-ones were synthesized by reacting the amino group of 3-cyclohexyl-2-hydrazino quinazolin$-4(3 H)$-one with a variety of aldehydes and ketones. The starting material, 3-cyclohexyl-2-hydrazino quinazolin$-4(3 H)$-one, was synthesized from cyclohexyl amine. Title compounds were investigated for analgesic, anti-inflammatory and ulcerogenic behavior. The compound 3-cyclohexyl-2-(1-methylbutylidene-hydrazino)-3H-quinazolin-4-one (4c) emerged as the most active compound of the series and is moderately more potent in its analgesic and anti-inflammatory activities compared to the reference standard diclofenac sodium. Interestingly, test compounds showed only mild ulcerogenic potential when compared to acetylsalicylic acid.
\end{abstract}

Keywords: quinazolin-4(3H)-one, analgesic activity, anti-inflammatory activity, ulcerogenicity

Nonsteroidal anti-inflammatory drugs (NSAIDs) are commonly prescribed for the treatment of acute and chronic inflammation, pain and fever. However, long-term clinical usage of NSAIDs is associated with significant side effects such as gastrointestinal lesions, bleeding, and nephrotoxicity. Therefore, discovery of new safer anti-inflammatory drugs represents a challenging goal in a research area (1-4). In our ongoing medicinal chemistry research program, we found that quinazolines and condensed quinazolines exhibit potent central nervous system (CNS) activity, including analgesic, anti-inflammatory (5) and anticonvulsant behavior (6). Quinazolin-4(3H)-ones with 2,3-substitution are reported to possess significant analgesic, anti-inflammatory $(7,8)$ and anticonvulsant

\footnotetext{
* Correspondence; e-mail: drvalagarsamy@gmail.com
} 
activitiy (9). We have earlier documented that some lead 2-phenyl-3-substituted quinazolines (10) (Fig. 1, I), 2-methyl-3-substituted quinazolines (11) (Fig. 1, II), 2-methylthio-3-substituted quinazaolines (12) (Fig. 1, III), and 2,3-disubstituted quinazolines (13) exhibited good analgesic and anti-inflammatory properties. The present work is an extension of our ongoing efforts towards the development and identification of new molecules for analgesic and anti-inflammatory activities with minimal gastrointestinal ulceration side effects. Against this background, in the present study we have synthesized a series of 3-cyclohexyl-2-substituted amino-quinazolin-4(3H)-ones. The synthesized compounds were tested for their analgesic, anti-inflammatory and ulcerogenic behavior.<smiles>CCN(CC)C(=S)Nn1c(-c2ccccc2)nc2ccccc2c1=O</smiles>

I<smiles>Cc1nc2ccccc2c(=O)n1NC(=S)n1cccc1</smiles>

II<smiles>CCN(CC)C(=S)Nn1c(SC)nc2ccccc2c1=O</smiles>

III

Fig. 1. Lead molecules of quinazolin-4-ones.

\section{EXPERIMENTAL}

Melting points were taken in open capillaries on a Thomas Hoover melting point apparatus (Thomas Hoover, USA) and are uncorrected. IR spectra were recorded in film or in potassium bromide disks on a Perkin-Elmer 398 spectrometer (Perkin-Elmer, USA). ${ }^{1} \mathrm{H}$ spectra were recorded on a DPX-300 MHz Bruker FT-NMR spectrometer (Bruker, USA). Chemical shifts were reported as parts per million $(\delta \mathrm{ppm})$ with tetramethylsilane (TMS) as an internal standard. Mass spectra were obtained on a Jeol-SX-102 instrument (Jeol, Japan) using fast atom bombardment (FAB positive). Elemental analysis was performed on a Perkin-Elmer $2400 \mathrm{CHN}$ analyzer (Perkin-Elmer) and values were within acceptable limits of the calculated values $( \pm 0.4 \%)$. Spectral data (IR, NMR and mass spectra) and elemental analysis data are presented in Tables I and II. The progress of the reaction was monitored on ready-made silica gel plates (Merck, Norway) using chloroform/methanol (9:1) as a solvent system. Iodine was used as a developing agent. All chemicals and reagents used in the synthesis were obtained from Aldrich (USA), Lancaster (USA) or Spectrochem (India) and were used without further purification.

\section{Syntheses}

3-Cyclohexyl-2-thioxo-2,3-dihydro-1H-quinazolin-4-one (1). - A solution of cyclohexyl amine $(0.02 \mathrm{~mol})$ in dimethyl sulphoxide $(10 \mathrm{~mL})$ was stirred vigorously. To this, carbon disulphide $(1.6 \mathrm{~mL})$ and aqueous sodium hydroxide $1.2 \mathrm{~mL}\left(2 \mathrm{~mol} \mathrm{~L}^{-1}\right)$ were added dropwise during $30 \mathrm{~min}$ under stirring. Dimethyl sulfate $(0.02 \mathrm{~mol})$ was added gradually keeping the reaction mixture stirred in a freezing mixture for $2 \mathrm{~h}$. The reaction mixture was then poured into ice water. The solid obtained was $N$-cyclohexyl-methyl dithiocarbamic acid, which was filtered, washed with water, dried and recrystallized from ethanol. Methyl anthranilate $(0.01 \mathrm{~mol})$ and the prepared $N$-cyclohexyl-methyl dithiocarbamic 
V. Alagarsamy et al.: Synthesis and pharmacological evaluation of 3-cyclohexyl-2-substituted hydrazino-3H-quinazolin-4-ones as analgesic and anti-inflammatory agents, Acta Pharm. 59 (2009) 75-88.

Table I. Physical and analytical data of synthesized compounds

\begin{tabular}{|c|c|c|c|c|c|c|c|}
\hline \multirow{2}{*}{ Compd. } & \multirow{2}{*}{$\begin{array}{l}\text { Mol. } \\
\text { formula }\end{array}$} & \multirow{2}{*}{$\begin{array}{l}\text { Molecular } \\
\text { mass }^{\mathrm{a}}\end{array}$} & \multirow{2}{*}{$\begin{array}{l}\text { M.p. } \\
\left({ }^{\circ} \mathrm{C}\right)\end{array}$} & \multirow{2}{*}{$\begin{array}{c}\text { Yield } \\
(\%)\end{array}$} & \multicolumn{3}{|c|}{ Elemental analysis calcd./found (\%) } \\
\hline & & & & & C & $\mathrm{H}$ & $\mathrm{N}$ \\
\hline \multirow{2}{*}{1} & \multirow{2}{*}{$\mathrm{C}_{14} \mathrm{H}_{16} \mathrm{~N}_{2} \mathrm{OS}$} & \multirow{2}{*}{260} & \multirow{2}{*}{$250-251$} & \multirow{2}{*}{88} & 64.58 & 6.19 & 10.76 \\
\hline & & & & & 64.56 & 6.23 & 10.78 \\
\hline \multirow{2}{*}{2} & \multirow{2}{*}{$\mathrm{C}_{15} \mathrm{H}_{18} \mathrm{~N}_{2} \mathrm{OS}$} & \multirow{2}{*}{274} & \multirow{2}{*}{$180-182$} & \multirow{2}{*}{88} & 65.66 & 6.61 & 10.21 \\
\hline & & & & & 65.69 & 6.64 & 10.20 \\
\hline \multirow{2}{*}{3} & \multirow{2}{*}{$\mathrm{C}_{14} \mathrm{H}_{18} \mathrm{~N}_{4} \mathrm{O}$} & \multirow{2}{*}{258} & \multirow{2}{*}{$220-221$} & \multirow{2}{*}{81} & 65.09 & 7.02 & 21.69 \\
\hline & & & & & 65.05 & 7.03 & 21.64 \\
\hline \multirow{2}{*}{$4 a$} & \multirow{2}{*}{$\mathrm{C}_{18} \mathrm{H}_{24} \mathrm{~N}_{4} \mathrm{O}$} & \multirow{2}{*}{312} & \multirow{2}{*}{$238-239$} & \multirow{2}{*}{73} & 69.20 & 7.74 & 17.93 \\
\hline & & & & & 69.23 & 7.79 & 17.89 \\
\hline & $\mathrm{C}_{19} \mathrm{H}_{26} \mathrm{~N}_{4} \mathrm{O}$ & & & & 68.07 & 8.03 & 17.16 \\
\hline $4 \mathrm{~b}$ & $C_{19} \Pi_{26} \mathrm{~N}_{4} \mathrm{U}$ & 326 & $219-221$ & 78 & 68.02 & 8.08 & 17.19 \\
\hline & & & & & 68.07 & 8.03 & 17.16 \\
\hline $4 \mathrm{c}$ & $\mathrm{C}_{19} \mathrm{H}_{26} \mathrm{~N}_{4} \mathrm{U}$ & 326 & $247-248$ & 72 & 68.11 & 8.00 & 17.14 \\
\hline $4 d$ & $\mathrm{C}_{20} \mathrm{H}_{26} \mathrm{~N}_{4} \mathrm{O}$ & 360 & $281-282$ & 72 & 70.98 & 7.74 & 16.55 \\
\hline & $-20^{1} \mathrm{H}_{26^{\mathrm{N}}} \mathrm{C}_{4} \mathrm{U}$ & 360 & $281-282$ & 12 & 70.99 & 7.77 & 16.49 \\
\hline $4 e$ & $\mathrm{C}_{22} \mathrm{H}_{24} \mathrm{~N}_{4} \mathrm{O}$ & 338 & $228-230$ & 71 & 73.31 & 6.71 & 15.54 \\
\hline & 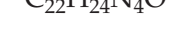 & & & $/ 1$ & 73.33 & 6.77 & 15.51 \\
\hline $4 \mathrm{f}$ & $\mathrm{C}_{2} \mathrm{H}_{2} \mathrm{~N}_{5} \mathrm{O}_{2}$ & 387 & $298-299$ & 73 & 68.20 & 5.46 & 18.08 \\
\hline & $22 \alpha_{21}+v_{5} \mho_{2}$ & & & & 68.27 & 5.48 & 18.06 \\
\hline $4 \mathrm{~g}$ & $\mathrm{C}_{21} \mathrm{H}_{22} \mathrm{~N}_{4} \mathrm{O}$ & 346 & $248-250$ & 73 & 72.80 & 6.40 & 16.17 \\
\hline & ${ }_{21}+2_{22^{+}} 4^{\circ}$ & & & & 72.83 & 6.43 & 16.12 \\
\hline $4 \mathrm{~h}$ & $\mathrm{C}_{21} \mathrm{H}_{21} \mathrm{~N}_{4} \mathrm{OCl}$ & 381 & $221-222$ & 77 & 66.22 & 5.56 & 14.71 \\
\hline & $21^{2}-21^{2}+4=0$ & & & & 66.28 & 5.54 & 14.74 \\
\hline $4 i$ & $\mathrm{C}_{21} \mathrm{H}_{21} \mathrm{~N}_{4} \mathrm{OCl}$ & 381 & $285-286$ & 72 & 66.22 & 5.56 & 14.71 \\
\hline & $211_{21}+4=01$ & & & & 66.20 & 5.52 & 14.77 \\
\hline $4 i$ & $\mathrm{C}_{27} \mathrm{H}_{21} \mathrm{~N}_{5} \mathrm{O}_{3}$ & 391 & $251-253$ & 79 & 64.44 & 5.41 & 17.89 \\
\hline & & & & 19 & 64.48 & 5.43 & 17.82 \\
\hline $4 \mathrm{k}$ & $\mathrm{C}_{21} \mathrm{H}_{21} \mathrm{~N}_{5} \mathrm{O}_{3}$ & 391 & $210-212$ & 74 & 64.44 & 5.41 & 17.89 \\
\hline & & & & & 64.39 & 5.42 & 17.90 \\
\hline 41 & $\mathrm{C}_{22} \mathrm{H}_{24} \mathrm{~N}_{4} \mathrm{O}_{2}$ & 376 & $278-279$ & 80 & 70.19 & 6.43 & 14.88 \\
\hline & & & & & 70.11 & 6.44 & 14.93 \\
\hline $4 \mathrm{~m}$ & $\mathrm{C}_{22} \mathrm{H}_{24} \mathrm{~N}_{4} \mathrm{O}$ & 360 & $247-248$ & 71 & 73.30 & 6.71 & 15.54 \\
\hline & 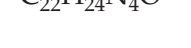 & 300 & $247-240$ & $/ 1$ & 73.34 & 6.68 & 15.51 \\
\hline $4 n$ & $\mathrm{C}_{22} \mathrm{H}_{24} \mathrm{~N}_{4} \mathrm{O}$ & 360 & $281-283$ & 70 & 73.30 & 6.71 & 15.54 \\
\hline & 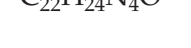 & & & 70 & 73.28 & 6.69 & 15.49 \\
\hline 40 & $\mathrm{C}_{27} \mathrm{H}_{26} \mathrm{~N}_{4} \mathrm{O}$ & 422 & $253-255$ & 73 & 76.75 & 6.20 & 13.26 \\
\hline & $\mathrm{C}_{27}+26^{+} \mathrm{I}_{4}$ & & & 10 & 76.71 & 5.23 & 13.29 \\
\hline
\end{tabular}

a Molecular mass determination by mass spectral analysis $\left(\mathrm{M}^{+}\right)$. 
V. Alagarsamy et al: Synthesis and pharmacological evaluation of 3-cyclohexyl-2-substituted hydrazino-3H-quinazolin-4-ones as analgesic and anti-inflammatory agents, Acta Pharm. 59 (2009) 75-88.

Table II. Spectral data of synthesized compounds

\begin{tabular}{|c|c|c|c|}
\hline Compd. & $\begin{array}{l}\text { IR }(\mathrm{KBr}) \\
\quad\left(\mathrm{cm}^{-1}\right)\end{array}$ & $\begin{array}{c}{ }^{1} \mathrm{H} \mathrm{NMR}\left(\mathrm{CDCl}_{3}\right) \\
(\delta, \mathrm{ppm})\end{array}$ & $\begin{array}{c}{ }^{13} \mathrm{C} \mathrm{NMR}\left(\mathrm{CDCl}_{3}\right) \\
(\delta, \mathrm{ppm})\end{array}$ \\
\hline 1 & $\begin{array}{l}3298(\mathrm{NH}) \\
1690(\mathrm{C}=\mathrm{O}) \\
1218(\mathrm{C}=\mathrm{S})\end{array}$ & $\begin{array}{l}0.90-2.11\left(\mathrm{~m}, 10 \mathrm{H}, \mathrm{CH}_{2} \text {-cyclohexyl), }\right. \\
7.32-7.84(\mathrm{~m}, 4 \mathrm{H}, \mathrm{ArH}), 10.35 \text { (br s, } \\
1 \mathrm{H}, \mathrm{NH} \mathrm{D}_{2} \mathrm{O} \text { exchangeable) }\end{array}$ & \\
\hline 2 & $\begin{array}{l}1670(\mathrm{C}=\mathrm{O}) \\
1619(\mathrm{C}=\mathrm{C})\end{array}$ & $\begin{array}{l}\text { 1.11-2.22 (m, 10H, } \mathrm{CH}_{2} \text {-cyclohexyl), } 2.53 \\
\left(\mathrm{~s}, 3 \mathrm{H}, \mathrm{SCH}_{3}\right), 7.24-7.75(\mathrm{~m}, 4 \mathrm{H} \mathrm{ArH})\end{array}$ & \\
\hline 3 & $\begin{array}{l}3330,3261 \\
\left(\mathrm{NHNH}_{2}\right) \\
1680(\mathrm{C}=\mathrm{O})\end{array}$ & $\begin{array}{l}0.80-1.91\left(\mathrm{~m}, 10 \mathrm{H}, \mathrm{CH}_{2} \text {-cyclohexyl), }\right. \\
4.32\left(\mathrm{~s}, 2 \mathrm{H}, \mathrm{NH}_{2}\right), 7.23-7.64(\mathrm{~m}, 4 \mathrm{H}, \mathrm{ArH}), \\
9.75\left(\mathrm{~s}, 1 \mathrm{H}, \mathrm{NH} \mathrm{D}_{2} \mathrm{O} \text { exchangeable }\right)\end{array}$ & $\begin{array}{l}20.2(2 \mathrm{C}), 26.5, \\
30.2(2 \mathrm{C}), 49.3, \\
119.2,121.3,126.5, \\
127.7,132.7,145.9, \\
158.5,162.7\end{array}$ \\
\hline $4 a$ & $\begin{array}{l}3310(\mathrm{NH}) \\
1683(\mathrm{C}=\mathrm{O}) \\
1610(\mathrm{C}=\mathrm{N})\end{array}$ & $\begin{array}{l}0.61-1.33\left(\mathrm{~m}, 10 \mathrm{H}, \mathrm{CH}_{2} \text {-cyclohexyl), }\right. \\
1.54-1.64\left(\mathrm{q}, 2 \mathrm{H}, \mathrm{CH}_{2} \mathrm{CH}_{3}\right), 1.74-1.80 \\
\left(\mathrm{t}, 3 \mathrm{H}, \mathrm{CH}_{2} \mathrm{CH}_{3}\right), 2.35\left(\mathrm{~s}, 3 \mathrm{H}, \mathrm{CH}_{3}\right) \\
7.01-7.33(\mathrm{~m}, 4 \mathrm{H}, \mathrm{ArH}), 8.33(\text { br s, } \\
1 \mathrm{H}, \mathrm{NH} \mathrm{D} \mathrm{D}_{2} \mathrm{O} \text { exchangeable) }\end{array}$ & $\begin{array}{l}6.7,12.7,21.7 \\
(2 \mathrm{C}), 25.6,27.3, \\
30.7(2 \mathrm{C}), 49.3 \\
118.5,121.1,126.9, \\
127.7,131.9,146.7 \\
157.9,160.5,162.3\end{array}$ \\
\hline
\end{tabular}

4 b $3273(\mathrm{NH}), \quad 0.55-1.21\left(\mathrm{~m}, 10 \mathrm{H}, \mathrm{CH}_{2}\right.$-cyclohexyl),

$1685(\mathrm{C}=\mathrm{O}), \quad 1.35-1.56\left(\mathrm{~m}, 4 \mathrm{H},\left(\mathrm{CH}_{2} \mathrm{CH}_{3}\right)_{2}\right), 1.77-1.96$

$1610(\mathrm{C}=\mathrm{N}) \quad\left(\mathrm{m}, 6 \mathrm{H},\left(\mathrm{CH}_{2} \mathrm{CH}_{3}\right)_{2}\right), 7.34-7.66(\mathrm{~m}, 4 \mathrm{H}, \mathrm{ArH})$, 8.15 (br s, $1 \mathrm{H}, \mathrm{NH} \mathrm{D}_{2} \mathrm{O}$ exchangeable)

4c $\quad 3311(\mathrm{NH}), \quad 0.80-1.43\left(\mathrm{~m}, 10 \mathrm{H}, \mathrm{CH}_{2}\right.$-cyclohexyl),

$1671(\mathrm{C}=\mathrm{O}), \quad 1.51-1.64\left(\mathrm{t}, 2 \mathrm{H}, \mathrm{CH}_{2} \mathrm{CH}_{2} \mathrm{CH}_{3}\right), 1.95-2.00$

$1612(\mathrm{C}=\mathrm{N}) \quad\left(\mathrm{sext}, 2 \mathrm{H}, \mathrm{CH}_{2} \mathrm{CH}_{2} \mathrm{CH}_{3}\right), 2.10-2.23(\mathrm{t}, 3 \mathrm{H}$, $\left.\mathrm{CH}_{2} \mathrm{CH}_{2} \mathrm{CH}_{3}\right), 2.42$ (s, 3H, $\left.\mathrm{CH}_{3}\right), 7.41-7.74$ $(\mathrm{m}, 4 \mathrm{H}, \mathrm{ArH}), 8.34$ (br s, $1 \mathrm{H}, \mathrm{NH} \mathrm{D}_{2} \mathrm{O}$ exchangeable)

4d $3266(\mathrm{NH}), \quad 0.57-1.91\left(\mathrm{~m}, 20 \mathrm{H}, \mathrm{CH}_{2}\right.$-cyclohexyl), $1692(\mathrm{C}=\mathrm{O}), \quad 7.21-7.63(\mathrm{~m}, 4 \mathrm{H}, \mathrm{ArH}), 8.73$ (br s, $1 \mathrm{H}$, $1615(\mathrm{C}=\mathrm{N}) \quad \mathrm{NH} \mathrm{D} \mathrm{D}_{2} \mathrm{O}$ exchangeable $)$

4e $3316(\mathrm{NH}), \quad 0.81-1.53\left(\mathrm{~m}, 10 \mathrm{H}, \mathrm{CH}_{2}\right.$-cyclohexyl), $1680(\mathrm{C}=\mathrm{O}), 1.94\left(\mathrm{~s}, 3 \mathrm{H}, \mathrm{CH}_{3}\right), 7.22-7.83(\mathrm{~m}, 9 \mathrm{H}$, $1612(\mathrm{C}=\mathrm{N}) \quad \mathrm{ArH}), 8.54(\mathrm{br} \mathrm{s}, 1 \mathrm{H}, \mathrm{NH} \mathrm{D} \mathrm{O}$ exchangeable)

$12.3,21.4(2 \mathrm{C})$, $26.7,30.7(2 \mathrm{C})$, $49.7,119.5,121.1$ $127.2,127.7,128.7$ (2C), $129.2(2 \mathrm{C})$, 131.9, 132.1, 133.7, $145.9,159.7,162.7$, 167.9

4f $3285(\mathrm{NH}), \quad 0.60-1.31\left(\mathrm{~m}, 10 \mathrm{H}, \mathrm{CH}_{2}\right.$-cyclohexyl), $1690(\mathrm{C}=\mathrm{O}), \quad 7.42-8.04(\mathrm{~m}, 8 \mathrm{H}, \mathrm{ArH}), 8.64$ (br s, 1H, $1610(\mathrm{C}=\mathrm{N}) \quad \mathrm{NH} \mathrm{D}_{2} \mathrm{O}$ exchangeable), 9.25 (br s, $1 \mathrm{H}$, $\mathrm{NH} \mathrm{D} 2 \mathrm{O}$ exchangeable) 
$4 \mathrm{~g} 3310(\mathrm{NH}), \quad 0.55-1.11\left(\mathrm{~m}, 10 \mathrm{H}, \mathrm{CH}_{2}\right.$-cyclohexyl), $1685(\mathrm{C}=\mathrm{O}), 6.57(\mathrm{~s}, 1 \mathrm{H}, \mathrm{CH}), 7.24-7.92(\mathrm{~m}, 9 \mathrm{H}, \mathrm{ArH})$, $1611(\mathrm{C}=\mathrm{N}) \quad 8.55\left(\mathrm{br} \mathrm{s}, 1 \mathrm{H}, \mathrm{NH} \mathrm{D}_{2} \mathrm{O}\right.$ exchangeable)

4h $3056(\mathrm{NH}), \quad 0.71-1.44\left(\mathrm{~m}, 10 \mathrm{H}, \mathrm{CH}_{2}\right.$-cyclohexyl), $1690(\mathrm{C}=\mathrm{O}), \quad 6.33$ (s, 1H, CH), 7.42-8.04 (m, 8H, ArH), $1612(\mathrm{C}=\mathrm{N}) \quad 8.54$ (br s, $1 \mathrm{H}, \mathrm{NH} \mathrm{D} \mathrm{D}_{2} \mathrm{O}$ exchangeable)

4i $3274(\mathrm{NH}), \quad 0.71-1.34\left(\mathrm{~m}, 10 \mathrm{H}, \mathrm{CH}_{2}\right.$-cyclohexyl), $1678(\mathrm{C}=\mathrm{O}), 6.04(\mathrm{~s}, 1 \mathrm{H}, \mathrm{CH}), 7.11-7.27(\mathrm{~m}, 8 \mathrm{H}$, $1613(\mathrm{C}=\mathrm{N}) \quad \mathrm{ArH}), 8.32\left(\right.$ br s, $1 \mathrm{H}, \mathrm{NH} \mathrm{D} \mathrm{D}_{2}$ exchangeable)

4j $3326(\mathrm{NH}), \quad 0.56-1.26\left(\mathrm{~m}, 10 \mathrm{H}, \mathrm{CH}_{2}\right.$-cyclohexyl), $1690(\mathrm{C}=\mathrm{O}), 6.45(\mathrm{~s}, 1 \mathrm{H}, \mathrm{CH}), 7.33-7.88(\mathrm{~m}, 8 \mathrm{H}$, $1612(\mathrm{C}=\mathrm{N}) \quad \mathrm{ArH}), 8.34\left(\right.$ br s, $1 \mathrm{H}, \mathrm{NH} \mathrm{D} \mathrm{D}_{2}$ exchangeable)

4k $3260(\mathrm{NH}), \quad 0.91-1.64\left(\mathrm{~m}, 10 \mathrm{H}, \mathrm{CH}_{2}\right.$-cyclohexyl), $1681(\mathrm{C}=\mathrm{O}), 6.35(\mathrm{~s}, 1 \mathrm{H}, \mathrm{CH}), 7.34-7.84(\mathrm{~m}, 8 \mathrm{H}$, $1611(\mathrm{C}=\mathrm{N}) \quad \mathrm{ArH}), 8.25\left(\mathrm{br} \mathrm{s}, 1 \mathrm{H}, \mathrm{NH} \mathrm{D} \mathrm{D}_{2} \mathrm{O}\right.$ exchangeable)

$413332(\mathrm{NH}), \quad 1.15-1.74\left(\mathrm{~m}, 10 \mathrm{H}, \mathrm{CH}_{2}\right.$-cyclohexyl), $1690(\mathrm{C}=\mathrm{O}), \quad 3.43\left(\mathrm{~s}, 3 \mathrm{H}, \mathrm{OCH}_{3}\right), 6.45(\mathrm{~s}, 1 \mathrm{H}, \mathrm{CH})$, $1617(\mathrm{C}=\mathrm{N}) \quad 7.44-7.95(\mathrm{~m}, 8 \mathrm{H}, \mathrm{ArH}), 8.77$ (br s, $1 \mathrm{H}, \mathrm{NH} \mathrm{D}_{2} \mathrm{O}$ exchangeable)

$4 \mathrm{~m} 3310(\mathrm{NH}), \quad 0.77-1.33\left(\mathrm{~m}, 10 \mathrm{H}, \mathrm{CH}_{2}\right.$-cyclohexyl), $1690(\mathrm{C}=\mathrm{O}), 1.95\left(\mathrm{~s}, 3 \mathrm{H}, \mathrm{CH}_{3}\right), 6.44(\mathrm{~s}, 1 \mathrm{H}, \mathrm{CH})$, $1617(\mathrm{C}=\mathrm{N}) \quad 7.12-7.74(\mathrm{~m}, 8 \mathrm{H}, \mathrm{ArH}), 8.74(\mathrm{~s}, 1 \mathrm{H}$, $\mathrm{NH} \mathrm{D}_{2} \mathrm{O}$ exchangeable)

4n $3354(\mathrm{NH}), \quad 0.62-1.22\left(\mathrm{~m}, 10 \mathrm{H}, \mathrm{CH}_{2}\right.$-cyclohexyl), $1688(\mathrm{C}=\mathrm{O}), \quad 1.64\left(\mathrm{~s}, 3 \mathrm{H}, \mathrm{CH}_{3}\right), 6.00(\mathrm{~s}, 1 \mathrm{H}, \mathrm{CH})$, $1615(\mathrm{C}=\mathrm{N}) \quad 7.52-8.01(\mathrm{~m}, 8 \mathrm{H}, \mathrm{ArH}), 8.34$ (br s, $1 \mathrm{H}, \mathrm{NH} \mathrm{D}_{2} \mathrm{O}$ exchangeable)
$21.7(2 \mathrm{C}), 27.1$, $30.7(2 \mathrm{C}), 49.1$, $118.7,121.9,126.3$, $127.5,128.7(2 \mathrm{C})$, $129.9,130.2(2 \mathrm{C})$, $131.9,135.7,141.7$, $145.7,159.9,162.7$

$21.7(2 \mathrm{C}), 27.4$, 29.3 (2C), 49.5, $118.9,120.9(2 \mathrm{C})$, 125.5, 127.4, 127.9, 129.5 (2C), 132.9, $138.5,141.9,145.9$, $149.7,160.7,162.8$

21.4 (2C), 23.7, $27.1,29.9(2 \mathrm{C})$, 49.1, 118.6, 119.9 (2C), 125.9, 126.9, $127.9,129.5(2 \mathrm{C})$, $132.9,138.5,141.9$ $145.9,149.7,160.1$, 161.9

4o $3310(\mathrm{NH}), \quad 0.94-1.64\left(\mathrm{~m}, 10 \mathrm{H}, \mathrm{CH}_{2}\right.$-cyclohexyl), $1687(\mathrm{C}=\mathrm{O}), \quad 3.33\left(\mathrm{~s}, 3 \mathrm{H}, \mathrm{OCH}_{3}\right), 7.22-8.03(\mathrm{~m}$, $1611(\mathrm{C}=\mathrm{N}) \quad 14 \mathrm{H}, \mathrm{ArH}), 8.34\left(\mathrm{br} \mathrm{s}, 1 \mathrm{H}, \mathrm{NH} \mathrm{D} \mathrm{D}_{2} \mathrm{O}\right.$ exchangeable) 
V. Alagarsamy et al: Synthesis and pharmacological evaluation of 3-cyclohexyl-2-substituted hydrazino-3H-quinazolin-4-ones as analgesic and anti-inflammatory agents, Acta Pharm. 59 (2009) 75-88.

acid $(0.01 \mathrm{~mol})$ were dissolved in ethanol $(20 \mathrm{~mL})$. To this, anhydrous potassium carbonate $(100 \mathrm{mg})$ was added and refluxed for $20 \mathrm{~h}$. The reaction mixture was cooled in ice and the solid separated was filtered and purified by dissolving in $10 \%$ alcoholic sodium hydroxide solution and re-precipitated by treatment with dilute hydrochloric acid. The solid obtained was filtered, washed with water, dried and recrystallized from ethanol.

3-Cyclohexyl-2-methylsulfanyl-3H-quinazolin-4-one (2). - 3-Cyclohexyl-2-thioxo-2,3-dihydro- $1 \mathrm{H}$-quinazolin-4-one (1) $(0.01 \mathrm{~mol})$ was dissolved in $40 \mathrm{~mL}$ of $2 \%$ alcoholic sodium hydroxide solution. To this, dimethylsulfate $(0.01 \mathrm{~mol})$ was added dropwise under stirring. The stirring was continued for $1 \mathrm{~h}$, the reaction mixture was then poured into ice water. The solid obtained was filtered, washed with water, dried and recrystallized from the ethanol/chloroform $(75: 25)$ mixture.

3-Cyclohexyl-2-hydrazino-3H-quinazolin-4-one (3). - 3-Cyclohexyl-2-methylsulfanyl$3 \mathrm{H}$-quinazolin-4-one (2) $(0.01 \mathrm{~mol})$ was dissolved in ethanol $(25 \mathrm{~mL})$. To this, hydrazine hydrate $(99 \%)(0.1 \mathrm{~mol})$ and anhydrous potassium carbonate $(100 \mathrm{mg})$ were added and refluxed for $29 \mathrm{~h}$. The reaction mixture was cooled and poured into ice water. The solid so obtained was filtered, washed with water, dried and recrystallized from the chloroform/benzene (25:75) mixture.

General synthetic procedure for 3-cyclohexyl-2-substituted hydrazino-3H-quinazolin-4-ones (4a-o). - A mixture of 3-cyclohexyl-2-hydrazino-3H-quinazolin-4-one (3) (0.004 mol) and appropriate ketone/aldehyde $(0.004 \mathrm{~mol})$ in glacial acetic acid was refluxed for $41 \mathrm{~h}$. The reaction mixture was poured into ice water. The solid obtained was filtered, washed with water, dried under high vacuum and recrystallized from ethanol.

\section{Pharmacology}

The synthesized compounds were evaluated for analgesic, anti-inflammatory and ulcerogenic activity. Test compounds and standard drugs were administered in the form of a suspension ( $1 \%$ carboxymethylcellulose as a vehicle) by oral route of administration for analgesic and anti-inflammatory studies, but for ulcerogenicity studies intraperitoneally as suspension in $10 \%(\mathrm{~V} / \mathrm{V})$ Tween 80 . Each group consisted of six animals. The animals were maintained in colony cages at $25 \pm 2{ }^{\circ} \mathrm{C}$, relative humidity of $45-55 \%$, under a $12 \mathrm{~h}$ light and dark cycle; they were fed standard animal feed. All the animals were acclimatized for a week before the experiment. The Institutional Animal Ethics Committee approved the protocol adopted for experimentation on animals.

Analgesic activity. - Test for analgesic activity was performed by the tail-flick technique $(14,15)$ using Wistar albino mice $(25-35 \mathrm{~g})$ of either sex selected by random sampling technique. Diclofenac sodium, at dose levels of 10 and $20 \mathrm{mg} \mathrm{kg}^{-1}$, was administered orally as reference drug for comparison. The test compounds at two dose levels (10 and $20 \mathrm{mg} \mathrm{kg}^{-1}$ ) were administered orally. The reaction time was recorded at $30 \mathrm{~min}, 1,2$ and $3 \mathrm{~h}$ after the treatment, and the cut-off time was $10 \mathrm{~s}$.

Anti-inflammatory activity. - Anti-inflammatory activity was evaluated by the carrageenean-induced paw oedema method (16). Sixteen groups of albino Wistar rats of either sex weighing 150-200 g, 6 animals each, were orally dosed with the tested compounds at two dose levels (10 and $20 \mathrm{mg} \mathrm{kg}^{-1}$ ). Diclofenac sodium, 10 and $20 \mathrm{mg} \mathrm{kg}^{-1}$, was 
V. Alagarsamy et al.: Synthesis and pharmacological evaluation of 3-cyclohexyl-2-substituted hydrazino-3H-quinazolin-4-ones as analgesic and anti-inflammatory agents, Acta Pharm. 59 (2009) 75-88.

administered as standard drug for comparison. Paw volumes were measured using the mercury displacement technique with the help of a plethysmograph immediately after and $30 \mathrm{~min}, 1,2$ and $3 \mathrm{~h}$ after carrageenean injection.

Ulcerogenicity index. - Wistar Albino rats weighing 150-200 g, of either sex, were divided into sixteen groups of six animals each (17). Animals were administered the test compounds intraperitoneally at a dose of $20 \mathrm{mg} \mathrm{kg}^{-1}$ (17). The control group of animals was administered only $10 \%(\mathrm{~V} / \mathrm{V})$ Tween 80 suspension intraperitoneally. One group was administered acetylsalicylic acid (Ranbaxy, India) intraperitoneally at a dose of $20 \mathrm{mg}$ $\mathrm{kg}^{-1}$ once daily for three days. On the fourth day, pylorus was ligated as per the reported method (18). Animals were fasted for $36 \mathrm{~h}$ before the pylorus ligation procedure. Four hours after the ligation, animals were sacrificed. The stomach was removed and opened along the greater curvature. Ulcer index was determined by the reported method (19).

\section{Statistical analysis}

Statistical analysis of the biological activity of synthesized compounds on animals was evaluated using a one-way analysis of variance (ANOVA). In all cases, posthoc comparisons of the means of individual groups were performed using Tukey's test. All values were expressed as mean \pm SD. The GraphPad Prism 3.0 version was used for statistical analysis.

\section{RESULTS AND DISCUSSION}

The key intermediate 3-cyclohexyl-2-thioxo-2,3-dihydro-1H-quinazolin-4-one (1) was prepared from cyclohexyl amine with carbon disulphide and sodium hydroxide in dimethyl sulphoxide to give sodium dithiocarbamate, which was methylated with dimethyl sulfate to afford the dithiocarbamic acid methyl ester. The later refluxed with methyl anthranilate in ethanol yielded the desired compound 1 via the thiourea intermediate in a good yield. IR spectra of compound 1 showed intense peaks at $3298 \mathrm{~cm}^{-1}$ for cyclic thiourea $(\mathrm{NH}), 1690 \mathrm{~cm}^{-1}$ for carbonyl $(\mathrm{C}=\mathrm{O})$ and $1218 \mathrm{~cm}^{-1}$ for thioxo $(\mathrm{C}=\mathrm{S})$ stretching. ${ }^{1} \mathrm{H}$ NMR spectrum of 1 showed a multiplet at $\delta 0.91-2.02$ and 7.33-7.84 ppm for cyclohexyl $(10 \mathrm{H})$ protons and aromatic $(4 \mathrm{H})$ protons, respectively, and a singlet at $\delta 10.35$ ppm, indicating the presence of $\mathrm{NH}$. Further, the molecular ion recorded $\left(m / z 260\left[\mathrm{M}^{+}\right]\right)$ in the mass spectrum is also in agreement with the molecular mass of the compound.

3-Cyclohexyl-2-methysulfanyl-3H-quinazolin-4-one (2) was obtained by dissolving 1 in $2 \%$ alcoholic sodium hydroxide solution and methylating with dimethyl sulfate under stirring at room temperature. The IR spectrum of compound 2 showed disappearance of $\mathrm{NH}$ and $\mathrm{C}=\mathrm{S}$ stretching signals of cyclic thiourea. It showed a peak for carbonyl $(\mathrm{C}=\mathrm{O})$ stretching at $1690 \mathrm{~cm}^{-1}$. The ${ }^{1} \mathrm{H}$ NMR spectrum of compound 2 showed singlets due to $\mathrm{SCH}_{3}$, a multiplet at $\delta 1.10-2.21$ and 7.22-7.73 ppm for cyclohexyl (10H) protons and aromatic $(4 \mathrm{H})$ protons, respectively. Molecular ion recorded in the mass spectrum $\left(m / z 274\left[\mathrm{M}^{+}\right]\right)$further confirmed the assigned structure.

Nucleophilic displacement of the methylthio group of 2 with hydrazine hydrate was carried out using ethanol as solvent to afford 3-cyclohexyl-2-hydrazino-3H-quinazolin- 
V. Alagarsamy et al: Synthesis and pharmacological evaluation of 3-cyclohexyl-2-substituted hydrazino-3H-quinazolin-4-ones as analgesic and anti-inflammatory agents, Acta Pharm. 59 (2009) 75-88.

-4-one (3). The long duration of reaction (29 h) required might be due to the presence of the bulky cyclohexyl ring at position 3, which might have reduced the reactivity of quinazoline ring system at the C-2 position. The formation of 3 was confirmed by the ${ }^{1} \mathrm{H}$ NMR spectrum singlets at $\delta 4.32$ and 9.73 ppm due to $\mathrm{NH}_{2}$ and $\mathrm{NH}$, respectively, a multiplet at $\delta$ 0.80-1.91 and 7.24-7.65 ppm for cyclohexyl $(10 \mathrm{H})$ protons and aromatic $(4 \mathrm{H})$ protons, respectively. The $\mathrm{NH}$ and $\mathrm{NH}_{2}$ signals at $3330-3261 \mathrm{~cm}^{-1}$ appeared in the IR

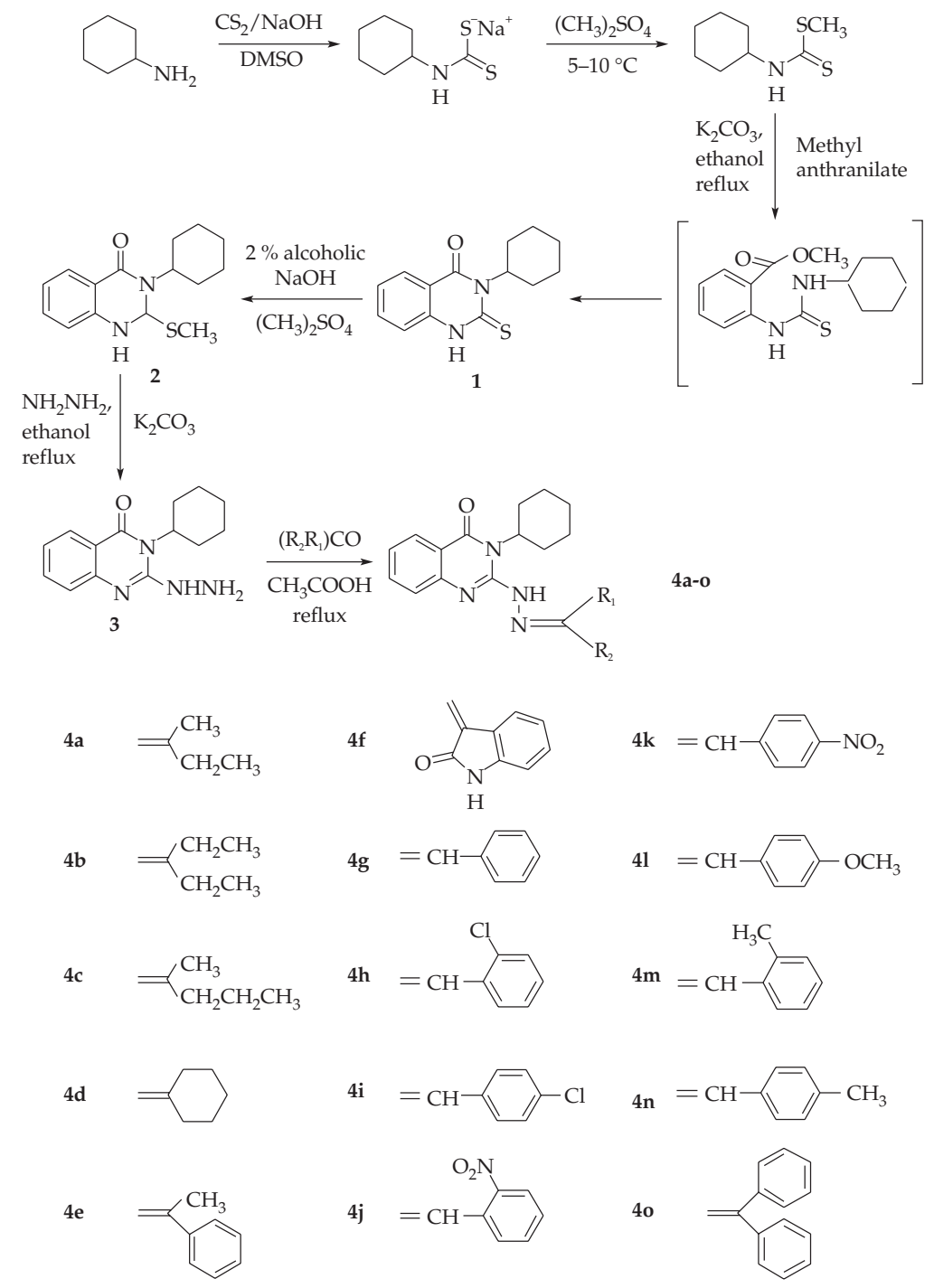

Scheme 1 
V. Alagarsamy et al.: Synthesis and pharmacological evaluation of 3-cyclohexyl-2-substituted hydrazino-3H-quinazolin-4-ones as analgesic and anti-inflammatory agents, Acta Pharm. 59 (2009) 75-88.

spectrum. It also showed a peak for carbonyl $(\mathrm{C}=\mathrm{O})$ at $1680 \mathrm{~cm}^{-1}$. Further, the molecular ion recorded in the mass spectrum $\left(\mathrm{m} / z 258\left[\mathrm{M}^{+}\right]\right)$is also in agreement with the molecular mass of the compound.

The title compounds, 3-cyclohexyl-2-substituted hydrazino-3H-quinazolin-4-ones (4a-o), were obtained by condensation of the amino group of 3-cyclohexyl-2-hydrazino$-3 \mathrm{H}$-quinazolin-4-one (3) with a variety of aldehydes and ketones. Formation of the title product is indicated by the disappearance of peak due to $\mathrm{NH}_{2}$ of the starting material in IR and ${ }^{1} \mathrm{H}$ NMR spectra of all compounds $4 \mathbf{a}-\mathbf{o}$. The IR and ${ }^{1} \mathrm{H}$ NMR spectra of these compounds showed the presence of peaks due to $\left(\mathrm{N}=\mathrm{CR}_{1} \mathrm{R}_{2}\right)$, carbonyl $(\mathrm{C}=\mathrm{O}), \mathrm{NH}$ and aryl groups. Mass spectra of the title compounds showed molecular ion peaks corresponding to their molecular formula. In mass spectra of compounds $4 \mathbf{a}-\mathbf{0}$, a common peak at $m / z 144$ corresponding to quinazolin-4-one moiety appeared. The $\mathrm{M}^{+}+2$ peaks were observed in the spectra of compounds $4 \mathrm{~h}$ and $4 \mathbf{i}$, confirming the presence of a chlorine atom in the compounds. The relative intensities of these $\mathrm{M}^{+}+2$ peaks in comparison with $\mathrm{M}^{+}$ peaks were in a ratio 1:3. Elemental analysis satisfactorily confirmed elemental composition and purity of the synthesized compounds.

The results of analgesic testing indicated that the test compounds exhibited moderate analgesic activity after $30 \mathrm{~min}$ of reaction time and an increase in activity after $1 \mathrm{~h}$, reaching the peak level after $2 \mathrm{~h}$. Decline in activity was observed after $3 \mathrm{~h}$ (Table III). Compound 4a with 1-methylpropylidene substituent showed good activity; with increased lipophilicity of 1-ethylpropylidene group compound $4 \mathrm{~b}$ showed an increase in activity. After replacement of 1-ethylpropylidene group with its isomer 2-pentylidene group compound $4 \mathrm{c}$ retained its activity. Replacement of an alkyl chain at the 2-position with a cycloalkyl group and an aralkyl group (compounds $\mathbf{4} \mathbf{d}$ and $\mathbf{4 e}$, respectively) led to moderate decrease in activity. Placement of an aryl group at the $\mathrm{N}-3$ position (compounds $4 \mathbf{f}$, $4 \mathrm{~g}$ and $\mathbf{4 m - o}$ ) also resulted in decreased activity. Placement of an electron withdrawing group at the N-3 aryl ring (compounds $4 \mathrm{~h}-1$ ) led to further decrease of activity.

The anti-inflammatory activity data (Table IV) indicate that all the test compounds moderately protected rats from carrageenean-induced inflammation after $30 \mathrm{~min}$ of reaction time, with increased activity after $1 \mathrm{~h}$ that reached the peak level after $2 \mathrm{~h}$. Decline in activity was observed after $3 \mathrm{~h}$. Compound 3-cyclohexyl-2-(1-methyl butylidene-hydrazino)-3H-quinazolin-4-one (4c) emerged as the most active anti-inflammatory agent and it is more potent compared to the reference standard diclofenac sodium.

The ulcer index of the test compounds (Table V) reveals that the compounds with open-chain aliphatic substituents (compounds 4a-c) showed a negligible ulcer index, whereas aryl substituents (compounds $4 \mathrm{e}-\mathrm{g}$ and $4 \mathrm{~m}-\mathbf{o}$ ) exhibited little increase in the ulcer index and the aryl substituents containing electron withdrawing groups (compounds $4 \mathbf{h}-\mathbf{l}$ ) exhibited a higher ulcer index then other test compounds. When compared to the reference standard acetylsalicylic acid (ulcer index $1.73 \pm 0.41$ ) and diclofenac (ulcer index $1.65 \pm 0.59)$, the test compounds exhibited about 35 to $50 \%$ of the ulcer index of reference standards. Compound 3-cyclohexyl-2-(1-methylpropylidene-hydrazino)-3H-quinazolin-4-one (4a) exhibited the lowest ulcer index $(0.45 \pm 1.51)$ among the test compounds wherease the compound 3-cyclohexyl-2-( $N^{\prime}$-(2-nitro-benzylidene-hydrazino)-3H-quinazolin-4-one (4j) showed the highest ulcer index $(0.79 \pm 1.26)$ among the test compounds.

In our earlier studies, we observed that the presence of alkyl groups exhibited more analgesic and anti-inflammatory activities then aryl groups at the N-3 position of qui- 
V. Alagarsamy et al: Synthesis and pharmacological evaluation of 3-cyclohexyl-2-substituted hydrazino-3H-quinazolin-4-ones as analgesic and anti-inflammatory agents, Acta Pharm. 59 (2009) 75-88.

Table III. Analgesic activity of test compounds (tail-flick technique)

\begin{tabular}{|c|c|c|c|c|c|}
\hline \multirow{2}{*}{ Compd. } & \multirow{2}{*}{$\begin{array}{c}\text { Dose } \\
\left(\mathrm{mg} \mathrm{kg}^{-1}\right)\end{array}$} & \multicolumn{4}{|c|}{ Analgesic activity (\%) ${ }^{\mathrm{a}}$} \\
\hline & & $30 \mathrm{~min}$ & $1 \mathrm{~h}$ & $2 \mathrm{~h}$ & $3 \mathrm{~h}$ \\
\hline \multirow{2}{*}{$4 a$} & 10 & $61 \pm 2^{c}$ & $66 \pm 2^{c}$ & $68 \pm 2^{c}$ & $36 \pm 1^{\mathrm{d}}$ \\
\hline & 20 & $73 \pm 2^{c}$ & $77 \pm 2^{c}$ & $80 \pm 2^{c}$ & $45 \pm 2^{c}$ \\
\hline \multirow{2}{*}{$4 b$} & 10 & $65 \pm 1^{c}$ & $69 \pm 1^{c}$ & $74 \pm 1^{c}$ & $38 \pm 1^{c}$ \\
\hline & 20 & $74 \pm 1^{\mathrm{c}}$ & $78 \pm 1^{c}$ & $83 \pm 2^{c}$ & $47 \pm 1^{c}$ \\
\hline \multirow{2}{*}{$4 c$} & 10 & $67 \pm 1^{c}$ & $70 \pm 2$ & $77 \pm 2^{c}$ & $41 \pm 1^{c}$ \\
\hline & 20 & $78 \pm 2^{c}$ & $81 \pm 2^{c}$ & $85 \pm 1^{c}$ & $50 \pm 1^{c}$ \\
\hline \multirow{2}{*}{$4 d$} & 10 & $45 \pm 1^{c}$ & $51 \pm 1^{c}$ & $54 \pm 1^{c}$ & $31 \pm 1^{\mathrm{e}}$ \\
\hline & 20 & $57 \pm 1^{c}$ & $60 \pm 2^{c}$ & $65 \pm 2^{\mathrm{e}}$ & $39 \pm 1$ \\
\hline \multirow{2}{*}{$4 e$} & 10 & $52 \pm 1^{c}$ & $56 \pm 2^{c}$ & $58 \pm 1^{c}$ & $34 \pm 1$ \\
\hline & 20 & $63 \pm 2^{c}$ & $67 \pm 2^{c}$ & $70 \pm 2^{c}$ & $41 \pm 1^{\mathrm{e}}$ \\
\hline \multirow{2}{*}{$4 \mathrm{f}$} & 10 & $48 \pm 1^{c}$ & $51 \pm 1^{c}$ & $52 \pm 2^{c}$ & $29 \pm 1^{c}$ \\
\hline & 20 & $59 \pm 1^{\mathrm{c}}$ & $62 \pm 2^{c}$ & $63 \pm 1$ & $37 \pm 1^{\mathrm{e}}$ \\
\hline \multirow{2}{*}{$4 \mathrm{~g}$} & 10 & $45 \pm 2^{c}$ & $49 \pm 1^{c}$ & $52 \pm 1^{c}$ & $30 \pm 1^{d}$ \\
\hline & 20 & $57 \pm 1^{c}$ & $62 \pm 1^{c}$ & $64 \pm 2$ & $39 \pm 2$ \\
\hline \multirow{2}{*}{$4 \mathrm{~h}$} & 10 & $36 \pm 1$ & $44 \pm 2$ & $48 \pm 2^{\mathrm{e}}$ & $29 \pm 1^{c}$ \\
\hline & 20 & $45 \pm 1$ & $50 \pm 1^{c}$ & $56 \pm 1^{c}$ & $35 \pm 1^{c}$ \\
\hline \multirow{2}{*}{$4 i$} & 10 & $38 \pm 1$ & $43 \pm 2$ & $50 \pm 2^{\mathrm{d}}$ & $28 \pm 1^{c}$ \\
\hline & 20 & $51 \pm 1^{c}$ & $55 \pm 1$ & $59 \pm 2$ & $36 \pm 1^{\mathrm{d}}$ \\
\hline \multirow{2}{*}{$4 \mathbf{j}$} & 10 & $40 \pm 2$ & $48 \pm 1^{c}$ & $52 \pm 2^{c}$ & $29 \pm 1^{c}$ \\
\hline & 20 & $54 \pm 1^{c}$ & $57 \pm 1^{\mathrm{e}}$ & $62 \pm 1$ & $38 \pm 1$ \\
\hline \multirow{2}{*}{$4 \mathrm{k}$} & 10 & $40 \pm 2$ & $44 \pm 1$ & $47 \pm 2$ & $27 \pm 2^{c}$ \\
\hline & 20 & $49 \pm 1^{\mathrm{d}}$ & $52 \pm 1^{d}$ & $58 \pm 1^{\mathrm{e}}$ & $33 \pm 1^{c}$ \\
\hline \multirow{2}{*}{41} & 10 & $41 \pm 2^{\mathrm{e}}$ & $46 \pm 1^{\mathrm{d}}$ & $51 \pm 2^{c}$ & $29 \pm 1^{c}$ \\
\hline & 20 & $49 \pm 2^{\mathrm{d}}$ & $55 \pm 2$ & $59 \pm 2$ & $39 \pm 1$ \\
\hline \multirow{2}{*}{$4 m$} & 10 & $45 \pm 1^{c}$ & $48 \pm 1^{c}$ & $52 \pm 2^{c}$ & $31 \pm 1^{c}$ \\
\hline & 20 & $54 \pm 1^{c}$ & $57 \pm 2^{\mathrm{e}}$ & $61 \pm 2$ & $38 \pm 1$ \\
\hline \multirow{2}{*}{$4 n$} & 10 & $47 \pm 2^{c}$ & $52 \pm 1^{c}$ & $55 \pm 2^{c}$ & $30 \pm 1^{\mathrm{d}}$ \\
\hline & 20 & $59 \pm 1^{c}$ & $60 \pm 1^{c}$ & $63 \pm 1$ & $39 \pm 2$ \\
\hline \multirow{2}{*}{40} & 10 & $48 \pm 1^{c}$ & $50 \pm 2^{c}$ & $51 \pm 2^{c}$ & $32 \pm 1$ \\
\hline & 20 & $56 \pm 2^{c}$ & $58 \pm 1^{\mathrm{d}}$ & $63 \pm 2$ & $39 \pm 2$ \\
\hline Control $^{\mathrm{b}}$ & - & - & - & - & - \\
\hline \multirow{2}{*}{ Diclofenac } & 10 & $37 \pm 2$ & $43 \pm 1$ & $45 \pm 1$ & $33 \pm 1$ \\
\hline & 20 & $46 \pm 1$ & $55 \pm 1$ & $62 \pm 2$ & $39 \pm 1$ \\
\hline
\end{tabular}

a Mean \pm SD from six experiments done in duplicate.

b Control animals were administered orally $1 \%$ CMC.

Significant difference relative to diclofenac at the same time point and the same dosage: ${ }^{c} p<0.0001$, d $p<0.001$, e $p<0.01$. 
V. Alagarsamy et al: Synthesis and pharmacological evaluation of 3-cyclohexyl-2-substituted hydrazino-3H-quinazolin-4-ones as analgesic and anti-inflammatory agents, Acta Pharm. 59 (2009) 75-88.

Table IV. Anti-inflammatory activity of test compounds (carrageenean-induced paw oedema test)

\begin{tabular}{|c|c|c|c|c|c|}
\hline \multirow{2}{*}{ Compd. } & \multirow{2}{*}{$\begin{array}{c}\text { Dose } \\
\left(\mathrm{mg} \mathrm{kg}^{-1}\right)\end{array}$} & \multicolumn{4}{|c|}{ Anti-inflammatory protection (\%) } \\
\hline & & $30 \mathrm{~min}$ & $1 \mathrm{~h}$ & $2 \mathrm{~h}$ & $3 \mathrm{~h}$ \\
\hline \multirow{2}{*}{$4 a$} & 10 & $48 \pm 2^{c}$ & $51 \pm 1^{c}$ & $55 \pm 1^{c}$ & $30 \pm 2^{\mathrm{e}}$ \\
\hline & 20 & $56 \pm 1^{c}$ & $62 \pm 2^{c}$ & $65 \pm 2^{c}$ & $39 \pm 2^{e}$ \\
\hline \multirow{2}{*}{$4 b$} & 10 & $49 \pm 1^{\mathrm{c}}$ & $53 \pm 1^{\mathrm{c}}$ & $59 \pm 2^{c}$ & $35 \pm 2$ \\
\hline & 20 & $62 \pm 1^{c}$ & $66 \pm 1^{c}$ & $71 \pm 2^{c}$ & $43 \pm 2$ \\
\hline \multirow{2}{*}{$4 c$} & 10 & $50 \pm 2^{c}$ & $57 \pm 1^{\mathrm{c}}$ & $63 \pm 2^{c}$ & $36 \pm 1^{\mathrm{d}}$ \\
\hline & 20 & $65 \pm 2^{c}$ & $68 \pm 2^{c}$ & $74 \pm 2^{c}$ & $47 \pm 1^{\mathrm{c}}$ \\
\hline \multirow{2}{*}{$4 d$} & 10 & $40 \pm 2^{\mathrm{c}}$ & $42 \pm 1^{\mathrm{c}}$ & $48 \pm 2^{\mathrm{c}}$ & $30 \pm 2^{\mathrm{e}}$ \\
\hline & 20 & $49 \pm 2^{\mathrm{e}}$ & $55 \pm 1^{\mathrm{d}}$ & $59 \pm 1$ & $37 \pm 1^{\mathrm{c}}$ \\
\hline \multirow{2}{*}{$4 e$} & 10 & $44 \pm 2^{c}$ & $47 \pm 1^{\mathrm{c}}$ & $48 \pm 1^{c}$ & $30 \pm 2^{\mathrm{e}}$ \\
\hline & 20 & $52 \pm 1^{c}$ & $58 \pm 1^{c}$ & $61 \pm 1$ & $38 \pm 1^{\mathrm{c}}$ \\
\hline \multirow{2}{*}{$4 f$} & 10 & $38 \pm 2^{c}$ & $42 \pm 2^{c}$ & $47 \pm 1^{\mathrm{c}}$ & $30 \pm 2^{\mathrm{e}}$ \\
\hline & 20 & $49 \pm 1^{\mathrm{e}}$ & $51 \pm 1$ & $55 \pm 1^{d}$ & $39 \pm 1^{c}$ \\
\hline \multirow{2}{*}{$4 \mathrm{~g}$} & 10 & $37 \pm 2^{c}$ & $40 \pm 1^{\mathrm{e}}$ & $46 \pm 1^{\mathrm{c}}$ & $29 \pm 1^{c}$ \\
\hline & 20 & $48 \pm 1^{\mathrm{e}}$ & $50 \pm 2^{e}$ & $55 \pm 1^{d}$ & $35 \pm 1^{\mathrm{c}}$ \\
\hline \multirow{2}{*}{$4 \mathrm{~h}$} & 10 & $32 \pm 1$ & $35 \pm 1^{\mathrm{d}}$ & $39 \pm 1$ & $27 \pm 2^{c}$ \\
\hline & 20 & $41 \pm 2^{\mathrm{e}}$ & $42 \pm 1^{\mathrm{c}}$ & $49 \pm 1^{c}$ & $33 \pm 1^{c}$ \\
\hline \multirow{2}{*}{$4 i$} & 10 & $36 \pm 1^{c}$ & $38 \pm 1$ & $42 \pm 1^{\mathrm{e}}$ & $29 \pm 1^{c}$ \\
\hline & 20 & $42 \pm 1^{\mathrm{e}}$ & $49 \pm 1^{\mathrm{d}}$ & $51 \pm 1^{\mathrm{c}}$ & $36 \pm 1^{c}$ \\
\hline \multirow{2}{*}{$4 j$} & 10 & $37 \pm 1^{\mathrm{c}}$ & $40 \pm 1^{\mathrm{e}}$ & $45 \pm 1^{\mathrm{c}}$ & $27 \pm 1^{\mathrm{c}}$ \\
\hline & 20 & $45 \pm 1$ & $48 \pm 1^{\mathrm{c}}$ & $52 \pm 1^{c}$ & $35 \pm 2^{c}$ \\
\hline \multirow{2}{*}{$4 k$} & 10 & $32 \pm 2$ & $39 \pm 1$ & $39 \pm 1$ & $28 \pm 2^{c}$ \\
\hline & 20 & $43 \pm 2$ & $47 \pm 2^{c}$ & $52 \pm 2^{c}$ & $36 \pm 2^{c}$ \\
\hline \multirow{2}{*}{41} & 10 & $35 \pm 2^{d}$ & $38 \pm 2$ & $39 \pm 2$ & $28 \pm 1^{c}$ \\
\hline & 20 & $44 \pm 2$ & $47 \pm 2^{c}$ & $48 \pm 1^{\mathrm{c}}$ & $35 \pm 1^{\mathrm{c}}$ \\
\hline \multirow{2}{*}{$4 m$} & 10 & $41 \pm 1^{\mathrm{c}}$ & $46 \pm 1^{c}$ & $49 \pm 1^{c}$ & $29 \pm 1^{c}$ \\
\hline & 20 & $52 \pm 2^{c}$ & $52 \pm 2$ & $58 \pm 2$ & $36 \pm 2^{c}$ \\
\hline \multirow{2}{*}{$4 n$} & 10 & $37 \pm 2^{c}$ & $42 \pm 1^{\mathrm{c}}$ & $46 \pm 1^{\mathrm{c}}$ & $30 \pm 2^{\mathrm{e}}$ \\
\hline & 20 & $48 \pm 1^{\mathrm{e}}$ & $54 \pm 2^{e}$ & $57 \pm 1^{\mathrm{e}}$ & $40 \pm 1^{\mathrm{e}}$ \\
\hline \multirow{2}{*}{40} & 10 & $36 \pm 1^{\mathrm{c}}$ & $40 \pm 1$ & $42 \pm 1^{\mathrm{e}}$ & $31 \pm 2^{\mathrm{e}}$ \\
\hline & 20 & $51 \pm 1^{\mathrm{c}}$ & $56 \pm 1^{c}$ & $58 \pm 2$ & $39 \pm 1^{\mathrm{e}}$ \\
\hline Control $^{\mathrm{b}}$ & & - & - & - & - \\
\hline \multirow{2}{*}{ Diclofenac } & & $32 \pm 1$ & $38 \pm 1$ & $39 \pm 2$ & $33 \pm 1$ \\
\hline & & $45 \pm 2$ & $52 \pm 1$ & $60 \pm 2$ & $42 \pm 1$ \\
\hline
\end{tabular}

a Mean \pm SD from six experiments done in duplicate.

b Control animals were administered orally $1 \%$ CMC.

Significant difference relative to diclofenac at the same time point and the same dosage: ${ }^{c} p<0.0001$,

d $p<0.001$, e $p<0.01$. 
V. Alagarsamy et al: Synthesis and pharmacological evaluation of 3-cyclohexyl-2-substituted hydrazino-3H-quinazolin-4-ones as analgesic and anti-inflammatory agents, Acta Pharm. 59 (2009) 75-88.

Table V. Ulcerogenicity

\begin{tabular}{cc}
\hline Compd. & Ulcer index $^{\mathrm{a}}$ \\
\hline $\mathbf{4 a}$ & $0.45 \pm 1.51$ \\
$\mathbf{4 b}$ & $0.50 \pm 1.82$ \\
$\mathbf{4} \mathbf{c}$ & $0.50 \pm 1.75$ \\
$\mathbf{4 d}$ & $0.48 \pm 1.64$ \\
$\mathbf{4} \mathbf{e}$ & $0.61 \pm 1.23$ \\
$\mathbf{4 f}$ & $0.66 \pm 1.42$ \\
$\mathbf{4} \mathbf{g}$ & $0.64 \pm 1.82$ \\
$\mathbf{4 h}$ & $0.71 \pm 1.21$ \\
$\mathbf{4}$ & $0.73 \pm 1.54$ \\
$\mathbf{4}$ & $0.79 \pm 1.26$ \\
$\mathbf{4} \mathbf{k}$ & $0.74 \pm 1.71$ \\
$\mathbf{4 1}$ & $0.77 \pm 1.21$ \\
$\mathbf{4 m}$ & $0.58 \pm 1.23$ \\
$\mathbf{4 n}$ & $0.60 \pm 1.84$ \\
$\mathbf{4 0}$ & $0.59 \pm 1.65$ \\
Control & $0.15 \pm 0.33^{\mathrm{c}}$ \\
Diclofenac & $1.65 \pm 0.59$ \\
Acetylsalicylic acid & $1.73 \pm 0.41$ \\
\hline
\end{tabular}

a Mean \pm SD from six experiments done in duplicate.

b Control animals were administered $10 \%(V / V)$ Tween 80 (i.p.).

Significant difference relative to diclofenac: ${ }^{\mathrm{c}} p<0.0001$.

nazolin-3-yl-4(3H)-one (10-13). Hence, we also made a substitution at the C-2 position in such a way as to increase lipophilicity of the molecule. Placement of such a group enhanced the analgesic and anti-inflammatory activities. In the present study, the most active compound $4 \mathrm{c}$ exhibited 77 and $85 \%$ analgesic activity at 10 and $20 \mathrm{mg} \mathrm{kg}^{-1}$, dose levels respectively, after $2 \mathrm{~h}$. In contrast, diclofenac sodium showed 45 and $62 \%$ analgesic activity at 10 and $20 \mathrm{mg} \mathrm{kg}^{-1}$ dose levels, respectively, after $2 \mathrm{~h}$. The most active compound 4c showed 63 and $74 \%$ anti-inflammatory activity at doses of 10 and $20 \mathrm{mg} \mathrm{kg}^{-1}$, respectively, after $2 \mathrm{~h}$, whereas diclofenac sodium revealed 39 and $60 \%$ anti-inflammatory activity at doses of 10 and $20 \mathrm{mg} \mathrm{kg}^{-1}$, respectively, after the same time. Interestingly, compound $4 \mathrm{c}$ showed $35 \%$ of ulcer index of the reference NSAID's acetylsalicylic acid and diclofenac.

\section{CONCLUSIONS}

In the present study, synthesis of a new series of 3-cyclohexyl-2-substituted hydrazino-3H-quinazolin-4-ones (4a-o) has been described. Among the series, 3-cyclohexyl-2-(1-methylbutylidene-hydrazino)-3H-quinazolin-4-one (4c) emerged as the most active 
V. Alagarsamy et al.: Synthesis and pharmacological evaluation of 3-cyclohexyl-2-substituted hydrazino-3H-quinazolin-4-ones as analgesic and anti-inflammatory agents, Acta Pharm. 59 (2009) 75-88.

compound and it is moderately more potent in its analgesic and anti-inflammatory activities compared to the reference standard diclofenac sodium. Although this series could be developed as a novel class of analgesic and anti-inflammatory agents, further structural modifications are planned to increase the analgesic and anti-inflammatory activities with reduced ulcerogenicity.

\section{REFERENCES}

1. J. van Ryn and R. M. Botting, New insights into the mode of action of anti-inflammatory drugs, Inflamm. Res. 44 (1995) 1-10; DOI: 10.1007/BF01630479.

2. J. van Ryn, G. Trummlitz and M. Pairet, COX-2 selectivity and inflammatory processes, Curr. Med. Chem. 7 (2000) 1145-1161.

3. J. van Ryn, Inhibition of prostaglandin synthesis as a mechanism of action for aspirin-like drugs, Nature: New Biol. 231 (1971) 232-235.

4. M. Beuck, Nonsteroidal antiinflammatory drugs: A new generation of cyclooxygenase inhibitors, Angew. Chem. Int. Ed. 38 (1999) 631-633; DOI: 10.1002/(SICI)1521-3773(19990301)38:5<631:: AID-ANIE631>3.0.CO;2-S.

5. V. Alagarsamy, R. Revathi, S. Vijayakumar and K. V. Ramseshu, Synthesis and pharmacological investigation of some novel 2,3-disubstituted quinazolin-4(3H)-ones as analgesic and antiinflammatory agents, Pharmazie 58 (2003) 233-236; DOI: 10.1002/chin.200330182.

6. V. Alagarsamy, A. Thangathirupathy, S. C. Mandal, S. Rajasekaran, S. Vijayakumar, R. Revathi, J. Anburaj, S. Arunkumar and S. Rajesh, Pharmacological evaluation of 2-substituted $(1,3,4)$ thiadiazolo quinazolines, Indian J. Pharm. Sci. 68 (2006) 108-111.

7. A. E. Abdel-Rahman, E. A. Bakhite and E. A. Al-Taifi, Synthesis and antimicrobial testing of some new S-substituted-thiopyridines, thienopyridines, pyridothienopyrimidines and pyridothienotriazines, Pharmazie 58 (2003) 372-377; DOI: 10.1002/chin.200330182.

8. R. V. Chambhare, B. G. Khadse, A. S. Bobde and R. H. Bahekar, Synthesis and preliminary evaluation of some N-[5-(2-furanyl)-2-methyl-4-oxo-4H-thieno[2,3-d]pyrimidin-3-yl]-carboxamide and 3-substituted-5-(2-furanyl)-2-methyl-3H-thieno[2,3- $d$ ] pyrimidin-4-ones as antimicrobial agents, Eur. J. Med. Chem. 38 (2003) 89-100; DOI: 10.1002/chin.200328177.

9. N. A. Santagati, A. Caruso, V. M. C. Cutuli and F. Caccamo, Synthesis and pharmacological evaluation of thieno[2,3-d]pyrimidin-2,4-dione and 5H-pyrimido [5,4-b]indol-2,4-dione derivatives, Farmaco 50 (1995) 689-695.

10. V. Alagarsamy, V. R. Solomon, G. Vanikavitha, V. Paluchamy, M. R. Chandran, A. A. Sujin, A. Thangathiruppathy, S. Amuthalakshmi and R. Revathi, Synthesis, analgesic, anti-inflammatory and antibacterial activities of some novel 2-phenyl-3-substituted quinazolin-4(3H) ones, Biol. Pharm. Bull. 25 (2002) 1432-1435; DOI: 10.1248/bpb.25.1432.

11. V. Alagarsamy, G. Murugananthan and R. Venkateshperumal, Synthesis, analgesic, anti-inflammatory and antibacterial activities of some novel 2-methyl-3-substituted quinazolin-4-(3H)-ones, Biol. Pharm. Bull. 26 (2003) 1711-1714; DOI: 10.1248/bpb.26.1711.

12. V. Alagarsamy, R. Rajesh, R. Meena, S. Vijaykumar, K. V. Ramseshu and T. Duraianandakumar, Synthesis, analgesic, anti-inflammatory and antibacterial activities of some novel 2-methylthio-3-substituted quinazolin-4(3H)-ones, Biol. Pharm. Bull. 27 (2004) 652-656; DOI: 10.1248/bpb.27. 652.

13. V. Alagarsamy, V. Muthukumar, N. Pavalarani, P. Vasanthanathan and R. Revathi, Synthesis, analgesic and anti-inflammatory activities of some novel 2,3-disubstituted quinazolin-4(3H)-ones, Biol. Pharm. Bull. 26 (2003) 557-559; DOI: 10.1248/bpb.26.557. 
V. Alagarsamy et al.: Synthesis and pharmacological evaluation of 3-cyclohexyl-2-substituted hydrazino-3H-quinazolin-4-ones as analgesic and anti-inflammatory agents, Acta Pharm. 59 (2009) 75-88.

14. S. K. Kulkarni, Heat and other physiological stress-induced analgesia: Catecholamine mediated and naloxone reversible response, Life Sci. 27 (1980) 185-188; DOI: 10.1016/0024-3205(80)90136-8.

15. R. E. Amour and D. L. Smith, A method for determinating loss of pain sensation. J. Pharm. Exp. Ther. 72 (1941) 74-78.

16. C. A. Winter, E. A. Risely and G. W. Nuss, Carregeenin induced oedema in hind paw of the rat as assay for antiinflammatory drugs, Exp. Biol. Med. 111 (1962) 544-547.

17. R. K. Goyal, A. Chakrabarti and A. K. Sanyal, The effect of biological variables on the anti-ulcerogenic effect of vegetable plantain banana, Planta Med. 29 (1985) 85-88; DOI: 10.1055/s-2007-969412.

18. M. Shay, S. A. Komarov, D. Fels, D. Meranze, H. Grunstein and H. Siplet, A simple method for the uniform production of gastric ulceration in the rats, Gastroenterology 5 (1945) 43-61.

19. A. K. Ganguly and O. P. Bhatnagar, Effect of bilateral adrenalectomy on production of restraint ulcers in the stomach of albino rats, Can. J. Phys. Pharmacol. 51 (1973) 748-750.

\title{
$S A \check{Z} E T A K$
}

\section{Sinteza i farmakološka evaluacija 3-cikloheksil-2-supstituiranih hidrazino-3H-kinazolin-4-ona kao analgetika i antiinflamatorika}

\author{
VEERACHAMY ALAGARSAMY, DURAIRAJ SHANKAR, VISWAS RAJA SOLOMON, \\ RAJENDRA VASANT SHEOREY i PERIYASAMY PARTHIBAN
}

Reakcijom amino skupine 3-cikloheksil-2-hidrazino kinazolin-4(3H)-ona s različitim aldehidima i ketonima sintetizirani su novi 3-cikloheksil-2-supstituirani hidrazino-kinazolin-4(3H)-oni. Početni spoj 3-cikoheksil-2-hidrazino kinazolin-4(3H)-on pripravljen je iz cikloheksilamina. Sintetizirani spojevi testirani su na analgetsko i protuupalno djelovanje te ulcerogena svojstva. Spoj 3-cikloheksil-2-(1-metilbutiliden-hidrazino)-3H-kinazolin-4-on (4c) imao je najjače analgetsko i protuupalno djelovanje, nešto jače nego referentni spoj diklofenak natrij. Osim toga, testirani spojevi imaju samo blago ulcerogeno djelovanje $\mathrm{u}$ usporedbi s acetilsalicilnom kiselinom.

Ključne riječi: kinazolin-4(3H)-on, analgetsko djelovanje, protuupalno djelovanje, ulcerogenost Medicinal Chemistry Research Laboratory, MNR College of Pharmacy, Sangareddy-502294, India Department of Pharmacy (CARISM), SASTRA University, Tirumalaisamudram, Thanjavur-613402, India

Medicinal E Process Chemistry Division, Central Drug Research Institute, Lucknow-226001, India Department of Pharmacology, Institute of Pharmacy, Raipur Institute of Technology Raipur-492001, India 